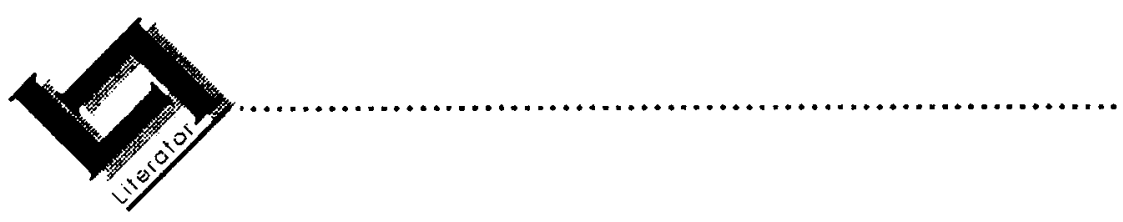

\title{
Crossing spatial and temporal boundaries: Three women in search of a future
}

\author{
Marita Wenzel \\ School of Languages and Arts: English \\ Potchefstroom University for CHE \\ POTCHEFSTROOM \\ E-mail: engmjw@puknet.puk.ac.za
}

\begin{abstract}
Crossing spatial and temporal boundaries: Three women in search of a future

The past has become a focal point in contemporary South African discourse, in public debate, newspaper articles and various forms of literature. South African literature written during the eighties and nineties, in particular English and Afrikaans novels, effectively portray this climate of confrontation and reconciliation by engaging in dialogue with the past and history. This article traces the evolution of political consciousness in the female protagonists of A Sport of Nature (1987) by Nadine Gordimer, Die reise van Isobelle (1996) by Elsa Joubert and Imaginings of Sand (1997) by Andre Brink. All three novelists subvert the traditional stereotypes of white women: Gordimer in an ironic quasi-picaresque form, Joubert by staging a family saga that assumes a testimonial quality and Brink in a fictionalised meta-history of women interwoven with strands of magic realism. The novels all engage with history, and in particular the role of women in history, in a constructive manner and attempt to anticipate a positive scenario for the future.
\end{abstract}

\section{History, fiction and reconciliation}

The past has become a focal point in contemporary South African discourse. Apart from public criticism levelled against the previous government, newspaper debates and articles on the subject, the establishment of the Truth and Reconciliation Commission has also created a particular forum for confrontation, reparation and reconciliation. This institution has not only initiated a process by which victims, or the relatives of victims, have been encouraged to come to terms with their 
situation but, in many instances, has also induced subsequent introspection and the acknowledgement of personal as well as collective guilt. However, reconciliation not only implies a dialogue or interaction between the past (history) and the present, the "coloniser" and "colonised"1, but also requires a process of re-orientation and the transgression of geographical, social (ideological) and mental boundaries for the construction of a positive future. It is in this re-vision of history and concomitant social debate that South African literature, and in particular the novel, plays a constructive role.

Reaction to the system op oppression in South Africa was already manifest in English literature during the fifties in the novels of Alan Paton and Nadine Gordimer and during the sixties, in the work of a historical group of dissident Afrikaans writers designated as the "Sestigers". André Brink was a prominent member of this group who could be regarded as the exponents of the modernist tradition in South Africa. During the period extending from the sixties to the eighties, both English and a large section of Afrikaans novels were written in the realist tradition with history and political issues as points of orientation. This situation changed with the advent of the eighties and nineties when postcolonial writers turned to strategies of re-writing, the subversion of master narratives, and modes such as magic realism and metafiction 2 .

The introduction of a new dispensation at the beginning of the nineties paved the way for the composition, or "imagining" 3 , of a new literature suitable for a "rainbow" nation. The result was a shift in focus from historical realism as theme to an awareness of history as part of the social text and context. This resulted in the "exciting signs of renewal and reinvention" (Brink, 1993:55) ${ }^{4}$ in South African literature that are also

1 Within the South African context, "coloniser" and "colonised" would conventionally be associated with European settlers and the indigenous peoples, respectively.

2 I refer here to several recent English novels published by authors such as Galgut, Botha, Coetzee, Conyngham, Landsman, Harries and many more, while Afrikaans literature has exponents such as Brink (who could be regarded as both Afrikaans and English), Joubert, Ferreira, Viljoen, Philips and Weideman, to mention but a few.

3 I use the term "imagining" here in the sense that Andre Brink (1993) talks about "reinventing" the real.

4 The debate about the literary "relevance" versus "excellence" (Holst Petersen, 1992:ii) has been a contentious subject in South African literary circles for some time. While critics such as Chapman (1992:3) maintain that South African literature should reflect political reality and act as a form of "participatory witness", recent works by writers such as Brink and Coetzee have favoured a more aesthetic-oriented approach based on conventions such as magic realism and allegory respectively. 
clearly evident in André Brink's oeuvre. The dialectic between fiction and history, or the interaction between text and context, has become an important literary device that Michael Green (1997) skilfully encapsulates in the title of his book, Novel Histories. The title, which could be read as new histories, histories of novels, or novels on history, intimates the possibility of different interpretations and emphasises the ambiguity of language and the complexity of social discourse. It also raises the question of different perspectives and the postmodernist tendency to erase the traditional boundaries between history and fiction. Consequently, history could be seen as fiction and fiction as history.

\section{The white woman in history/fiction}

Within the contemporary South African literary scene, the focus is increasingly placed on the many stories that have remained untold, the life stories and experiences of the oppressed and the marginalised that have been omitted from the historical documentation of the apartheid government. In South Africa the concerns of women had often been relegated to second position on the political agenda. However, since the 1980 s the plight of Third World and black women, who have been subjected to a double marginalization on account of race and gender, has been recognised and foregrounded in fiction and autobiographies by authors such as Miriam Tlali, Bessie Head and Ellen Kuzwayo. Yet white women also have their own story to tell as women and it is argued in this article that the emphasis on the victims of colonisation has perhaps obscured the problems of gender also shared by white women and has consigned them to stereotypical roles in society.

The white woman occupies a controversial role in history: she is either associated with the oppressor (coloniser) from an indigenous perspective, or perceived as part of the oppressed (colonised) as a woman dominated by the patriarchal and orthodox structures of authority. Both Susan Greenstein (1985:231) and Dorothy Driver (1988:3) remark on the unenviable role of women in colonial enterprise. While the former remarks on the perception of the white colonial woman in Africa as "both oppressor and ancillary victim", the latter asserts that "women were used by the patriarchal and imperialist system to reproduce the crucial dichotomies". To perceive white women simply as colonisers would tend to marginalise their contribution to South African history and literature rather than recognise their commonly shared interests with other women. 


\section{Three women in search of a future}

It is this stereotypical image of the white woman in South Africa that the three novels A Sport of Nature, Die reise van Isobelle and Imaginings of Sand attempt to subvert. The respective authors (Gordimer, Brink and Joubert) confront history and re-view it without ideological blinkers in the same way as Kristien, the narrator in Imaginings of Sand, acknowledges her role in history when she says: "I know the extent of my responsibility, and what it means to be exposed here to past and future alike, conscious of origins and possible endings" (59). Although published in 1987, A Sport of Nature shares the exploratory nature of the other two novels and reflects a sense of the "new, more inclusive political moment in South Africa", as Sarah Nuttall (1998:75) defines it.

All three the authors attempt to understand and define the particular role played by white women in South African history and society and to posit a plausible scenario for the future. This article is an attempt to determine how they counteract the stereotypical perceptions of white women who generally function within the limited confines of family, church and home in South African literature. It is extremely significant that a male author like André Brink participates in such an enterprise. His contribution not only emphasises the need to include women in South African history, but extends the historical perspective to incorporate indigenous women as an undeniable part of that history.

It is also significant that the conclusions of all three the novels discussed in this article demonstrate open and positive stances towards the future 5 . This feature highlights the function of literature as a form of social conscientization and as a barometer of social discourse. In a fascinating article on conclusions in Afrikaans novels that were published during 1993, Heilna Du Plooy (1995:46) identifies the novels' conclusions as points of orientation for readers. They act as implicit directives to action or introspection because they constitute a point or intersection at which fiction terminates and reality intrudes. She (Du Plooy, 1995:52) emphasises the implicit relationship between text and context when she states:

En as die skrywer en die leser in dieselfde wêreld, in dieselfde tydvak leef, sal die implisiete outeur se finale visie in die slot van die roman vir die karakters ' $n$ eskatologiese verwagting impliseer waarmee die leser van die teks weggaan.

5 As a matter of interest, The Devil's Chimney (1997) by Anne Landsman also shares this characteristic. 
The reader is left with a choice similar to that of Hillela, Leo and Kristien (characters in A Sport of Nature, Die reise van Isobelle and Imaginings of Sand respectively).

In contrast to the stereotypical images of women, the respective female protagonists, Hillela, Leo and Kristien, all endeavour to cross spatial and temporal boundaries in an attempt to determine their individual and social responsibility or "connection" to the past and South Africa. Their endeavours are graphically represented in the form of journeys which they undertake outside the borders of South Africa - journeys that form part of a metaphysical quest for identity (Burger, 1998:73). In the process they attain personal development and a growing sense of historical and political awareness which lead them to develop from situations of dependence to independence and finally interdependence. These novels then constitute an attempt to illustrate the necessity for re-vising the past and exposing the roots of and reasons for discrimination, as well as envisioning a positive resolution to the impasse of recrimination. In Hillela's case, she represents the culmination of several character traits such as the independence of spirit and freedom of choice developed in Gordimer's female protagonists in preceding novels - for instance, Rosa Burger and Maureen Smales. As far as Leo and Kristien are concerned, they both acknowledge their sense of political responsibility and freedom to choose their own future. The former as a legacy inherited from her ancestral female family members, and the latter, from her grandmother's accounts of her distant past and the feats of her remote ancestors.

Gordimer, Joubert and Brink all investigate the legacy of apartheid from different positions in the culture and gender spectrum. They also use different literary conventions. In a A Sport of Nature, Hillela conforms to the role of a picara in her search for identity. The fact that she attains a dubious status as the General's second wife at the conclusion, is typical of the ambivalent status of the picara because she becomes part of the hypocritical society that created her. Elsa Joubert traces the evolution of political consciousness in four generations of women to show the hidden obstacles of prejudice they had to overcome and André Brink reverts to a meta-history of women through the medium of magic realism to juxtapose past and present and make the past more relevant to the present.

\section{Gordimer's hybrid picara}

Gordimer's acute awareness of history and its interaction with context cannot be ignored in the interpretation of her work. As she is very conscious of the role of the writer in society and feels herself committed to expose social injustice in all its guises, "relevance" and "commitment" 
form the main tenets of her writing. Greenstein (1985:230) observes that Gordimer represents the white liberal writer's dilemma in attempting to render (an)other point of view while Judie Newman $(1985: 87)$ perceives Gordimer's fiction as an attempt "to free her art from Prospero's complex". Although she regards the feminist cause to be part of the political agenda, she frequently uses female protagonists to illustrate the interaction between personal lives and political issues.

The female protagonists in July's People (Gordimer, 1982) and Burger's Daughter (Gordimer, 1987), Maureen Smales and Rosa Burger respectively, provide an important backdrop for the character of Hillela in $A$ Sport of Nature. They explore the basic problems that Gordimer also experiences as an artist, namely, the struggle to establish a personal and social identity in a colonial, male-dominated, revolutionary society. Rosa and Maureen react to racial and social inequality in different measures and by different means. Rosa comes to the realisation that she is inextricably connected to the socio-political and historical reality of her time but she assumes responsibility on her own terms. Maureen, on the other hand, seems to take an impetuous step into an unknown future but it is her own choice for survival. ${ }^{6}$ Both these protagonists have to come to terms with the past in order to attempt a new future.

As protagonist, Hillela displays a combination of the features identified in Rosa and Maureen. She shows Rosa's independence and Maureen's adventurous and impetuous spirit. Her success can be attributed to her unconcern for social convention, her uncanny ability to adapt - an almost chameleon-like aptitude - and her disdain of hypocrisy. She follows a vagrant lifestyle with mostly shallow emotional ties - she mainly depends on physical relationships - with the result that her journey through life is strewn with transitory relationships. Cooper (1990:71) specifically comments on her sexuality which she perceives as a radical passion allowing Hillela to merge and flow "with her environment, her daughter, her friends, her lovers". This quality and her instinctive sense of survival are the main characteristics she displays in her travels and various affairs throughout Africa, Europe and America. Whether she acts as nursemaid, agent, lecturer, mother or wife she always manages to manipulate the situation in her favour. She blatantly exploits her sexuality to gain power: firstly as wife to a guerilla leader and then as second wife to a general. To her, the attainment of an individual, recognised female identity is

6 Brink (1994:176) argues that it is a logical conclusion and that it has "a much larger resonance" because "the assertiveness of Maureen's choice confirms it as an option (personal, sexual, political, cultural) for everybody e/se caught in the interregnum" (Brink, 1994:176). This action foreshadows Hillela's final solution to her own dilemma 
concomitant with political power. Consequently, although she emerges triumphant at the end as wife to the first black general to gain power in South Africa, her position seems uncertain and dependent on her sexuality.

The narrator is an important directive in Gordimer's fiction. As Martin (1986:4) astutely observes in a comparison between Coetzee and Gordimer, the role of the narrator is an attempt "to discover and understand (at least in part through the very act of narration) his or her own responsibility within that crisis". In this sense, the conclusions of the novels provide a significant insight into Gordimer's representation of the future of the white woman in South Africa. Although she exhibits a profound awareness of human nature and acknowledges the inevitable corruption of power, she seems to leave the responsibility squarely on the shoulders of the reader. Through Hillela she projects a possible solution in the form of adaptation to Africa as a hybrid, yet, the role of sexual power in this process is not sufficiently clear.

Gordimer seems to imply that the type of white women needed to survive in a multicultural South African society would have to move away from the basic oppositional stances represented by Hillela's two aunts and learn to adopt a more tolerant and liberated attitude. In a more recent novel, None to Accompany Me (Gordimer, 1994), she extends this vision of personal liberation to include a different kind of family scenario in which the protagonist, Vera, is divorced from her husband and no longer functions as an appendage to him. Her daughter Annie also deviates from the traditional mother image as a lesbian with an adopted black baby (Wagner, 1995:80)

\section{Joubert's family testimony}

On a personal level, Joubert also seems to be grappling with her past and her role as a white South African. In probably her best known novel, translated into English and published under the title Poppie, she attempts to act as facilitator in reconstructing the life of a black woman called Poppie (cf. Joubert, 1978). Her rendition of Poppie's account illustrates the unconscious irony (from Poppie's perspective) present in the relationship between Poppie's life and the political situation in South Africa. Although the role of facilitator is fraught with the pitfalls of ideological bias, her attempt is praiseworthy as a testimony to the lives of black people in South Africa, an acknowledgement of the female condition in general and the Third World woman's plight in particular.

Joubert's most recent novel, Die reise van Isobelle, also captures the quality of a testimonial account as an attempt to come to terms with the 
past and anticipate a new beginning. By juxtaposing the personal and political experience, Joubert sensitises the reader to consider a different perspective on historical reality; to assume a more sympathetic stance on political and historical events and, indirectly, adjust his/her original perception and interpretation of documented South African history. The novel illustrates an attempt to "rewrite history" from the coloniser's point of view (Van Coller, 1998:67).

Die reise van Isobelle assumes the proportions of a family saga which depicts the evolution of political consciousness in three consecutive generations of women from an Afrikaner family, the Van Veldens. However, as the lives of these women evolve against the backdrop of South African history spanning about a 100 years, their personal experiences become interwoven with and inextricable from the fabric of the relevant historical context.

The main thread linking all these personal histories is concerned with identity and political accountability. Agnes, married to the oldest Van Velden son, Stuart, suffers from a sense of rejection because she does not know the identity of her parents. It is with this psychological baggage that she joins the Van Velden family and seems to remain uncommitted to her marriage and life in general. This fact constitutes the greatest barrier to her happiness and causes her sister-in-law Leonora to become the role model for Agnes's daughter Belle (abbreviation of Isobelle) and her granddaughter Leo (named after Leonora). Aunt Leonora becomes an influential presence in the novel. In contrast with Agnes's neutrality, Leonora shows a surprisingly headstrong nature. She manages to travel and see the world; to enlarge her horizons. As a result, her broadened perspective and her innate honesty allow her to recognise injustice and speak out against it because she realises that one should respect life itself: "dis is nie wát die lewe is wat tel nie, maar dát die lewe is" (468). These ideas are also instilled in her niece, Belle and great niece Leo.

Agnes's daughter, Belle (Isobelle), grows up with independent views and is strongly influenced by her Afrikaans grandfather, Josias, in her opinions. When she visits her mother's childhood home in West Africa she meets and falls in love with the Indian boy, Hussein, and she experiences, first hand, the cruelty of discrimination and racism. When Hussein dies she flees to Europe in a bid to escape the trauma of a racist South Africa. Like her mother, Belle's personal tragedy and disillusionment cause her to withdraw physically and emotionally from life. She loses herself in the world of make-belief and film, a world of 
false emotions that make her immune to life (Reise: 383 ). ${ }^{7}$ Yet, Belle is not allowed to live her life in isolation as reality intrudes time and again to remind her of her social and political responsibility. For instance, she innocently and unwillingly becomes implicated in an immorality case (Reise: 409) that leaves her drained. She never regains her zest for life and it remains to her daughter, Leo, to confront reality and follow her conscience.

Although Leo is aware of squatter camps and poverty, she only confronts the reality of their existence when she becomes personally involved with the cause for freedom on inheriting her grandmother's house. When Leo meets the children living in the shed in her backyard, she begins to feel personally responsible for their well-being (Reise: 504). She becomes actively involved in the struggle when she starts teaching at a coloured school and is finally imprisoned for so-called subversive activities together with her boyfriend-cum-cousin, Fred, who works as a journalist. On their release from prison, Fred decides to accept a position overseas and Leo, who has become pregnant with his baby, is asked to make a choice: to accompany him or remain behind and raise her unborn child in South Africa. She decides to remain when she realises that her roots are here and it is her child's right to grow up in the country of his/her birth. Leo is optimistic about the future because she is in control of her life and feels a responsibility to future generations (Van Coller, 1998:65). Burger (1998:81) perceives her stance as an affirmation of belief in herself: "Dít wat haar ma nie kon regkry nie, daarvoor is sy sterk genoeg. En sy sien uit daarna om haar kind daarvoor groot te maak". She chooses her own future instead of allowing the past to dictate her actions because she is determined to live life to the full and vows that, if her child should be a girl, she would call her Isobelle, "voluit Isobelle" (Reise: 616). This final thought is preceded by an affirmation of faith in the future: "Wat ook al voorlê, nie wankelende ewewig nie. Eerder geloof in die moontlike verby die onmoontlike" (Reise: 616).

Joubert illustrates how individuals become embroiled in the official coils of history without realising the implications and repercussions. As Belle tells uncle Frikkie when he comes to visit her in Johannesburg, one is attached to one's environment/culture with such a potent glue that it leaves an open wound when one tears oneself away. It needs a conscious effort on the part of the individual to take a stance. It is this "glue" that fastens one to an ideology, blinds one to reality and causes

7 Die reise van Isobelle (Joubert, 1996) is henceforth referred to as Reise: relevant page number 
one not to see the wood for the trees. If Leonora was able to identify this debilitating adherence to a cause that distorted the perspective of her younger brothers, the readers should also be able to perceive the difference between ideology and reality.

\section{Brink, women and history}

In Imaginings of Sand, Brink interrogates the role of women in history by recounting, in the person of Ouma, the personal histories of her female ancestors. By using multiple narrators and resorting to magic realism, he subverts the "factual" content of history and draws attention to the suppressed voices of women in South African history. As a mode or genre, magic realism is very effective in the novel because it "serves as a site for cultural critique and change" (Bawarshi, 2000:336) and illustrates the essential duality of existence; the possibility of different interpretations of reality as well as providing the opportunity to experience and interpret the past (the unimaginable) first-hand. Especially the latter is significant because it highlights the complexity and chaotic reality of the past that resists the simplistic, orderly interpretation foisted on the reader by historical documentation. As Ouma implies in Imaginings of Sand, it is not truth per se that is significant but the fact that different versions of reality should be acknowledged. She reprimands her granddaughter Kristien for questioning the veracity of her stories: "I'm not asking you to believe me, Kristien. I'm only asking you to listen to me"'8 (Imaginings: 109). To deny her a voice would not only defeat the purpose of constructing a representative version of history, but would also only represent a partial account of the past. By implication, to make sense of the past, a variety of voices and a variety of techniques of interrogation have to be identified and accommodated.

Kristien, acts as facilitator and scribe for her grandmother's memories that assume bizarre proportions, grotesque shapes and surreal explanations. ${ }^{9}$ In this novel, Ouma, serves as the main exponent of magic realism when she becomes the medium between the ghosts of the past and the living characters of the present. The reader is confronted with a flock of birds hovering like spirits over Ouma's deathbed and is told about her nocturnal visits to and conversations with the dear departed in the family cemetery. She perceives it as her self-entrusted task to restore

8 Imaginings of Sand (Brink, 1997) is henceforth referred to as Imaginings: relevant page number.

9 We can perceive an interesting similarity with Isabel Allende's The House of the Spints here. 
Kristien's memory and sense of identity. When she reminds Kristien that being there and being seen are two different things (Imaginings: 270), she is expressing Brink's caution to the reader: that denying the existence of injustice, or the past for that matter, does not mean that it does not exist. This constitutes a central theme in the novel.

Whereas Kristien initially rejects the element of magic realism present in her grandmother's account, she later learns that it facilitates rather than obscures her understanding of the past and also helps her to relate to her immediate context. These supernatural visions then become an accepted part of reality and serve to represent the shadowline between truth and fiction, or at least to foster the recognition that memory of the past also operates within the present. As Kristien finally admits: "the unreality of all she makes me see lend reality only to the seeing itself" (Imaginings: 326).

After a self-imposed exile due to political convictions, Kristien returns home on the eve of the new dispensation with racial and gender discrimination still rife in society. Her interpretation of the situation is complemented and explicated by her grandmother's rendition of the past. Ouma senses Kristien's confusion, her lack of direction and historical awareness. She wants to leave her granddaughter with a legacy of hope and the only way she can do that is to give her back her "memory" (Imaginings: 325), which becomes synonymous with identity because, as Sarah Nuttall (1998:76) points out: "Memory is always as much about the present as it is about the past". In this way Ouma can restore her granddaughter's belief in herself as an Afrikaner and a woman (in the same way that Brink is trying to conscientize the reader). The implication is that one has to know one's origins to be able to understand a given situation.

Consequently, history assumes the guise of fiction. Kristien becomes the repository of the past which has to be unravelled, interpreted and reconciled with the present because, as she notes: "the very fabric of our fictions betrays the predicament of a culture" (Imaginings:130). Her recording of her family history and Ouma's oral account of it, provide the personal histories of women omitted from the annals of documented history. The fact that Ouma's stories exceed the boundaries of normality and verge on the supernatural, and that the lives and demise of Kristien's ancestors tend to assume legendary and fantastic proportions is unimportant, because Ouma wants Kristien to realize that the ending is a matter of choice. She should create her own ending and the lesson emerging from this rich and fascinating fabric of history and stories is twofold: trusting yourself (and your instinct) and realizing that choice is a privilege and responsibility. Ouma explains to Kristien: "If you don't know 
our history it becomes tempting to see everything that happens as your private fate. But once you know it you also realise you have a choice" (Imaginings: 324).

\section{Conclusion}

Gordimer, Joubert and Brink attempt to re-define and re-write, from a postcolonial perspective, the role of women in South African society and to emphasise their dual role as women and citizens. Similar to A Sport of Nature, in which Hillela acts as a hybrid of the disparate cultures, Leo's child represents a mixture of the past and the present. Its birth prognosticates a new kind of vision for the future. In contrast to Hillela, whose final position seems to hinge on her sexuality, Leo illustrates that personal commitment is concomitant with political conscientization and responsibility. Defying stereotypical roles, the new heroine offers an alternative and is able to assume various modes of independence. She turns herself into the subject of a discourse in which her female ancestors have so far featured as stereotypes and objects. Joubert's oeuvre illustrates the creative and regenerative ability of literature to reconstruct and rewrite the past.

In a similar vein, Brink also emphasises the role of women in assuming responsibility for their own future. Kristien effectively illustrates this idea when she realises that it is her responsibility to continue women's fight for justice or else all their suffering would have been in vain. She perceives her written account as an act of "foretelling" the past, similar to "the way prophets foretell the future" (Imaginings: 175) and realises the significance of choice when she resolves:

I have chosen this place, not because I was born here and feel destined to remain; but because I went away and then came back and now am here by choice. Perhaps for the first time in my life it is a decision that has not been forced on me from outside, by circumstances, but which has been shaped inside myself, like a child in the womb. This one I shall not deny. It is mine (Imaginings: 349 ).

However, in a much broader sense, Gordimer, Joubert and Brink also contribute towards the literary reconstruction of a "multi-voiced" history of their country. They rely on authentic historical/political events to constitute the social fabric of their novels and also engage in expanding the scope of creative literary invention. In particular, the conclusions of the above-mentioned novels give a good indication of the stance of the author as well as the reader's role and responsibility in the final process of cultural accommodation. As Wright (1992:30) argues, identity should 
not be consciously nurtured but individuals should be free to determine "the identity they want".

\section{Bibliography}

Bawarshi, Anis. 2000. The Genre Function. College English, 62(3):335-360.

Brink, André. 1993. Reinventing the Real: English South African Fiction Now. New Contrast, 21(1):44-55.

Brink, André. 1994. Complications of Birth: Interfaces of Gender, Race and Class in July's People. English in Africa, 21(1\&2):157-180.

Brink, André. 1997. Imaginings of Sand. London : Minerva.

Burger, Willie. 1998. Reis as ondergrawing van meesterverhale: Die reise van Ratkas en Isobelle. Literator, 19(3):69-83.

Chapman, Michael. 1992. The Critic in a State of Emergency: Towards a Theory of Reconstruction (after February 2). In: Holst Petersen, Kirsten \& Rutherford, Anna (eds.) On Shifting Sands: New Art and Literature from South Africa. Portsmouth : Dangaroo p. 1-13.

Cooper, Brenda. 1990. New Criteria for an 'Abnormal Mutation'? An Evaluation of Gordimer's A Sport of Nature. In: Trump, M. (ed.. Rendering Things Visible: Essays on South African Literary Culture. Johannesburg : Ravan Press. p. 6893.

Driver, Dorothy. 1988. 'Woman' as Sign in the South African Colonial Enterprise. Journal of Literary Studies, 4(1): 3-20.

Du Plooy, Heilna. 1995. Die mitologiserende slot van die roman. Stilet: Tydskrif van die Afrikaanse Letterkundevereniging, 7(2):46-61.

Gordimer, Nadine.1982. July's People. Harmondsworth : Penguin.

Gordimer, Nadine. 1987. Burger's Daughter. Harmondsworth : Penguin.

Gordimer, Nadine. 1987. A Sport of Nature. Cape Town : David Philip.

Gordimer, Nadine. 1994. None to Accompany Me. London : Bloomsbury.

Green, Michael. 1997. Novel Histories: Past, Present, and Future in South African Fiction. Johannesburg : Witwatersrand University Press.

Greenstein, Susan M. 1985. Miranda's Story: Nadine Gordimer and the Literarure of Empire. Novel: A Forum on Fiction, 18(3):227-242.

Holst Petersen, Kirsten. 1992. The Search for a Role for White Women in a Liberated South Africa: A Thematic Approach to the Novels of Nadine Gordimer. In: Holst Petersen, Kirsten \& Rutherford, Anna (eds.) On Shifting Sands: New Art and Literature from South Africa. Portsmouth : Dangaroo. p. 170-177

Joubert, Elsa. 1978. Die swerfjare van Poppie Nongena. Kaapstad : Tafelberg

Joubert Elsa. 1996. Die reise van Isobelle. Kaapstad : Tafelberg.

Landsman, Anne. 1997. The Devil's Chimney. Johannesburg : Jonathan Ball.

Martin, R.G. 1986. Narrative, History, Ideology: A Study of Waiting for the Barbarians and Burger's Daughter. Ariel: A Review of International English Literature, 17(1):3-21.

Newman, Judie 1985 Prospero's Complex Race and Sex in Nadine Gordimer's Burger's Daughter. The Journal of Commonwealth Literature, 20(1):81-99.

Nuttall, Sarah. 1998. Telling 'Free' Stories? Memory and Democracy in South African Autobiography since 1994. In: Nuttall, Sarah \& Coetzee, Carli (eds.) Negotiating the Past: The Making of Memory in South Africa. Cape Town : Oxford University Press. p. 75-88.

Van Coller, H.P. 1998. Die reisverslag van 'n post-kolonialistiese reisiger: Die Reise van Isobelle deur Elsa Joubert. Literator, 19(3):53-68 
Wagner, Kathrin. 1995. The Enigma of Arrival: Nadine Gordimer and the Politics of Identity in None to Accompany Me. The English Academy Review, 12:70-83.

Wright, Laurence. 1992. Some Thoughts on African Nationalism, Literary Education and the Post-Colonial University. Theoria: 25-30.

Key concepts:

A Sport of Nature - Nadine Gordimer Die reise van Isobelle - Elsa Joubert Imaginings of Sand - André Brink spatial and temporal boundaries subversion of female stereotypes women in South African literature

\section{Kernbegrippe:}

A Sport of Nature - Nadine Gordimer Die reise van /sobelle - Elsa Joubert Imaginings of Sand - André Brink ondermyning van vroulike stereotipes ruimtelike en temporele grense vroue in Suid-Afrikaanse letterkunde 